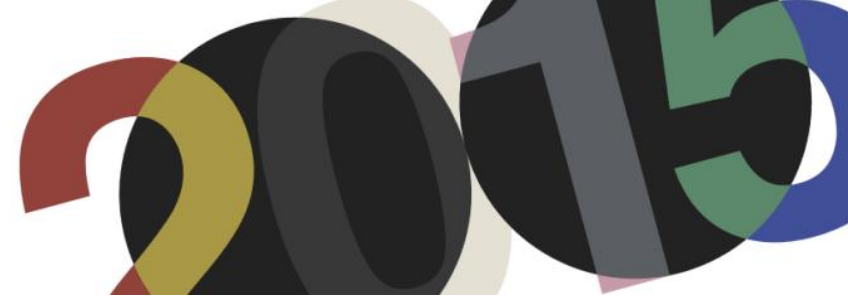

DOI: http://dx.doi.org/10.4995/LC2015.2015.915

\title{
Letter from the Basses-Pyrénnées: An Unintended Trigger for a Site Exchange
}

\author{
L. Martínez de Guereñu Elorza
}

IE University

\begin{abstract}
The contents of an unpublished letter (FLC I1-17-5), sent to Le Corbusier from the Basses-Pyrénées during the development of the Villa Ocampo project (1928), is the key to understanding the Swiss-French master's particular response to the site at the end of the 1920s. Countess Adela Cuevas de Vera, who negotiated the project from Anglet, revealed the Côte Basque as an attractive new market and claimed Le Corbusier's presence there. Furthermore, she reminded him of the prevailing regionalism and the strong cultural identity of the place, as well as the fact that Robert Mallet-Stevens, a great competitor of his, had already embarked there. Whatever the content of this letter awakened in Le Corbusier, led him to submit a very similar version of the third Villa Meyer project (1925) (designed for Paris) to be built in Buenos Aires. This paper re-evaluates the reasons behind a site exchange between two Southern cities on different sides of the Atlantic, studying the role of the negotiation site in the design process; and reassesses Le Corbusier's critical attitude towards regionalism, mapping out his relationship with a French region in which he never intervened. Through primary source research, this paper also recognizes that in architecture, rivalry, pride and ambition can quite often be authentic triggers for action.
\end{abstract}

Resumen: El contenido de una carta inédita (FLC I1-17-5), enviada a Le Corbusier desde los Bajos Pirineos durante el desarrollo del proyecto de la Villa Ocampo (1928), es la clave para entender la muy particular respuesta al lugar del maestro suizo-francés a finales de los años 20. La Condesa Adela Cuevas de Vera, que negoció el proyecto desde Anglet, presentó a Le Corbusier la Côte Basque como un atractivo mercado, al tiempo que reclamó allí su presencia. Le habló del regionalismo imperante y de la fuerte identidad cultural del lugar, recordándole que Robert Mallet-Stevens, un gran competidor suyo, había desembarcado ya allí. La reacción a esta carta llevó a Le Corbusier a entregar un proyecto muy similar a la tercera versión del proyecto de la Villa Meyer (1925) (proyectado para París) para ser construido en Buenos Aires. Este artículo reevalúa las razones que pueden existir tras el intercambio de lugar entre dos ciudades del Sur situadas a los dos lados del Atlántico, estudiando para ello el papel que el lugar de negociación juega en el desarrollo de un proyecto; y reexamina la actitud crítica de Le Corbusier hacia el regionalismo, mapeando su relación con una región francesa en la que nunca intervino. A través de la investigación de fuentes primarias, este artículo muestra también cómo la rivalidad, el orgullo y la ambición pueden asimismo ser auténticos desencadenantes para la acción durante el desarrollo de un proyecto.

Keywords: Site; negotiation; pragmatism; universalism; regionalism; dwelling.

Palabras clave: Lugar; negociación; pragmatismo; universalidad; regionalismo; habitar.

\section{Introduction}

It is already common knowledge that Le Corbusier and Pierre Jeanneret literally retraced the third version of the Parisian project of Villa Meyer (1925) and submitted it as a project for a house meant to be built in Buenos Aires. The Villa Ocampo (1928) was commissioned under quite unusual circumstances. It had to be designed in little over a month for a site on the other side of the Atlantic. The client, Victoria Ocampo, did not lead directly with the architects, but through Countess Adela Cuevas de Vera, who negotiated the project from Anglet.

Several attempts have been made to justify the pragmatic attitude Le Corbusier and Pierre Jeanneret displayed when deciding to re-use a project that had been specifically designed for another place. None of them seem to be 
convincing enough, especially in the context of the most recent reassessment of Le Corbusier's work. ${ }^{1}$ However, the contents of a forgotten letter, left out of the reconstruction project documents of Villa Ocampo, ${ }^{2}$ may now be the key to understanding Le Corbusier's particular response to the site. It is the third letter Adela Cuevas de Vera sent on September 6, 1928, asking Le Corbusier to submit the "first idea" of the house.

Adela Cuevas de Vera was able to reveal the Basses-Pyrénées ${ }^{3}$ as an attractive new market and to claim the presence of Le Corbusier there: "When will you come here? They are building tremendously, and above all, they are dividing up plots, they are constructing a new cliff road between St. Jean de Luz and Hendaye on uninhabited land...how wonderful if you could line this route with beautiful houses!" "Furthermore, Adela Cuevas de Vera reminded Le Corbusier of the prevailing regionalism and the strong cultural identity of the Basses-Pyrénées, as well as the fact that a great competitor of his had already embarked there. "Mallet Stevens has made a Casino in the bay of St. Jean de Luz. It does not have a pretty outline, but at least it is better than the Basque style, and it offers an idea of what could be done." That was an effective letter: by September 18, Le Corbusier had already finished the plans for Victoria Ocampo.

The fact that Robert Mallet-Stevens was already working at the Côte Basque might have been a stimulus for Le Corbusier, since at that time he was seen as a quite successful architect. In 1924, Adolf Loos had described him as "the most modern architect in France;" ${ }^{\prime 6}$ his Tourism Pavilion for the Exposition des Arts Décoratifs (1925) had received great critical acclaim and he had even managed to build an entire cul-de-sac in Auteil, named after him; Rue Mallet-Stevens (1925-27). Moreover, Le Corbusier, who had explicitly ridiculed regionalism in Vers une architecture, probably viewed the Basses-Pyrénées as a challenging region in which to test his architectural principles.

The aim of this paper is to re-evaluate the reasons behind a site exchange between Paris and Buenos Aires, studying the role of the negotiation site in a design process; to reassess Le Corbusier's critical attitude towards

\footnotetext{
${ }^{1}$ Cohen, Jean-Louis (Ed.), Le Corbusier: An Atlas of Modern Landscapes, New York: Museum of Modern Art, 2013.

${ }^{2}$ In the reconstruction of the Villa Ocampo documents, Hernán Marchant mentions the first letter, from August 9, 1928, the second letter, from August 27, 1928, and a final letter from September 29, 1928, but ceases to acknowledge the key letter, the third one from September 6, 1928. See Marchant, Hernán, "Villa Ocampo. 1928" (Project 25, DVD 2), in Le Corbusier Plans, Paris: Codex Images International/ Fondation Le Corbusier, 2005. Tim Benton recognizes the existence of the letter from September 6, 1928, and he even comments that Countess de Vera asked "for a first study," so that she could "radio [Victoria Ocampo] with her opinion," but he does not mention the contents that is considered of primary relevance for the hypothesis of this paper. See Benton, Tim, The Villas of Le Corbusier and Pierre Jeanneret 1920-1930, Basel-Boston-Berlin : Birkhäuser, 2007, p. 146. Josep Quetglas does not explicitly talk about the exchange of correspondence between Countess de Vera and Le Corbusier, but he suggests how Le Corbusier must have seen "something other than the construction of another villa” in Victoria Ocampo's commission. See Quetglas, Josep, Les Heures Claires, Sant Cugat del Vallés: Massilia, 2008, p. 30. It is this suspicion of him that led me to search through the exchange of correspondence between Le Corbusier, Countess de Vera and Victoria Ocampo, and to formulate the hypothesis of this paper.

${ }^{3}$ The Basses-Pyrenées is one of the original French departments created during the French revolution on March 4, 1790, out of the Béarn province (including Basse-Navarre), the lands of Labourd and Soule, and some parts belonging to the former greater province of Guyenne and Gascony. Labour, Basse-Navarre, and Soule form the three provinces of the French Basque Country. The Basses-Pyrenées were renamed Pyrenées-Atlantiques on October 10, 1969.

4 "Quand viendrez vous par ici? On bâtit énormément, et surtout on lotît, on construit une nouvelle corniche entre St. Jean de Luz et Hendaye dans des terrains inhabités... quelles merveille si vous pourriez border cette route de jolies maisons!," dossier Vera, FLC I1-17-5-002, FLC I1-17-5-003, September 6, 1928.

5 "Mallet Stevens à fait un Casino sur la baie de St. J. de Luz, il n'est pas joli de ligne, mais tout-de même c'est mieux que le style basque, et il donne une idée de ce que l'on pourrait faire," dossier Vera, FLC I1-17-5-003, September 6, 1928.

6 Adolf Loos, “'L'inhumaine.' Histoire féerique,” in Adolf Loos. Escritos II 1910/1932, El Croquis, El Escorial, Madrid, 1993, pp. 198-201. Originally published in Neue Freie Presse, Vienna, July 29, 1924.
} 
regionalism; and to map out the relationship Le Corbusier had with the Basses-Pyrénées, a French region in which he never intervened.

\section{Negotiation Site}

On August 9, 1928, and from 62, Rue de Varenne in Paris, Countess Adela Cuevas de Vera sent an off-the-cuff letter to Le Corbusier to say that she was in charge of consulting him about the construction of a modern house and also to request seeing the houses he had built in Auteil. ${ }^{7}$ Le Corbusier and Countess Cuevas de Vera had probably met the previous month of May in Madrid, when the Swiss-French master lectured at the Residencia de Estudiantes. ${ }^{8}$ However, the first trace of creative exchange between them goes back to September 1927, when she had already asked him to send "photographs, plans or prints of his houses.",

On August 27, 1928, and from Villa Delphine in Anglet, Countess Cuevas de Vera sent a much more thorough letter asking whether he could design a project for Madame Ocampo, ${ }^{10}$ who wanted to build a house in Buenos Aires "in the style that [they liked], especially in regards to the functional interior." 11 In order to satisfy the everyday activities, the house would need to include, among other requirements, a layout for a kitchen and an office similar to the one at the Villa in Garches, a series of well-placed cupboards in all serving rooms, and an elevator. As for the interior-exterior relationship, the house would need to have a façade without terraces on the Salguero Street side, a terrace opening onto the garden side, and a roof garden. Le Corbusier was even asked to create something of a similar nature for the interior terrace of the Villa in Garches, which would be "ideal for the light and the sky in Argentina, especially in polychromy." 12

Victoria Ocampo already had another project, from another architect, which she did not like, and which she would need to start constructing if she did not find an alternate solution before October $1^{\text {st }}$. Countess de Vera

\footnotetext{
7 There is no reference to the client or to the construction site on this first letter. "Monsieur. Je suis chargée de vous consulter pour l'édification d'une maison moderne d'out on voudrais que plus tard vous fassiez les plans. Je suis à Paris jusque à Lundi pro claim et voudrais parle avec vous et surtout voir les maisons que vous avec bâties à Auteil," dossier Vera, FLC I1-17-11001, FLC I1-17-11-002, August 9, 1928.

8 "Je reçois votre aimable lettre du 12 décembre me demandant d'aller à Madrid y faire quelques conférences...J'aurai je le souhaite, l'honneur et le plaisir de vous rencontrer à Madrid au printemps," dossier Vera, FLC C3-5-287-001, January 4, 1928.

9 "Je vieux vous demander s'il vous serait possible de ni envoyer quelques photographies, dessins or gravure de vos maisons," dossier Vera, FLC I1-17-9-001, September 2, 1927. During that time, Adela Cuevas de Vera was trying to negotiate the project of a house for herself, which they left for the near future. "Je suis décidée d'après ce que vous me dites, à attendre que les chantiers soient organisés ici pour construire la maison que je souhaite avoir, et pur laquelle je voudrais tout ce que vous pouvez rêver de plus nouveau," dossier Vera, FLC I1-17-1-003, August 27, 1928.

${ }^{10}$ Countess Cuevas de Vera was a rich Argentinian woman who gained access to the circles of European aristocracy by marrying Carlos Caro y Potestad, Count Cuevas de Vera, in Biarritz in 1915. She lived in Madrid as a maid of honor to the Queen until the fall of the Spanish monarchy. Victoria Ocampo, an influential Argentinian who would launch the journal Sur in 1931, had a long and ambivalent friendship with Countess Cuevas de Vera; she respected her opinion, but very often drove her out of her mind. See Juan José Sebreli, Cuadernos, Sudamericana, 2011.

11 "Mon amie, madame Ocampo dont je vous ai parlé veut construire une maison a Buenos Aires dans le style que vous aimons, surtout pour la partie pratique intérieure," dossier Vera, FLC I1-17-1-002, August 27, 1928. One of the lectures Le Corbusier gave in Madrid (and that Countess Cuevas de Vera must have attended) was precisely related to the activities of the modern house, "Architecture, furniture, and works of art." See in relation to the contents of the lecture Fernando García Mercadal, "Le Corbusier en Madrid," in La Gaceta Literaria 34, May 15, 1928 and Le Corbusier : Madrid 1928 : una casaun palacio [exposición], Residencia de Estudiantes, mayo-julio 2010, Residencia de Estudiantes, Madrid, 2010.

12 "Croyez vous possible de faire sur la coté jardin quelque chaise dans le genre daba térrasse intérieure de la Maisons de Garches...? Cela serait idéal, sur tour polychromie pour notre lumière et ciel,” dossier Vera, FLC I1-17-1-007, August 27, 1928.
} 
attached the four plans Victoria Ocampo had drawn herself and that showed the programmatic requirements [Fig. 1] as well as a photograph of another house she had built on the edge of the sea in Argentina, so that Le Corbusier could imagine the type of openings that could be made in Buenos Aires [Fig. 2]. ${ }^{13}$ Countess de Vera explicitly clarified that he would not be able to introduce the type of windows he usually made, and also that the house would naturally be built by Madame Ocampo's architect "with the elements of the country." 14 The question mark Le Corbusier added to the letter beside this sentence shows his perplexity towards the proposal, and may even be an index of how stunned he must have been by all these unconventional requirements. Given the amount of work he and Pierre Jeanneret had at their office during the summer of 1928 (Centrosoyuz in Moscú, Mundaneum in Genéve, Villa Savoye in Poissy, etc), and the fact that he did not know Buenos Aires, Le Corbusier initially ignored this strange commission.
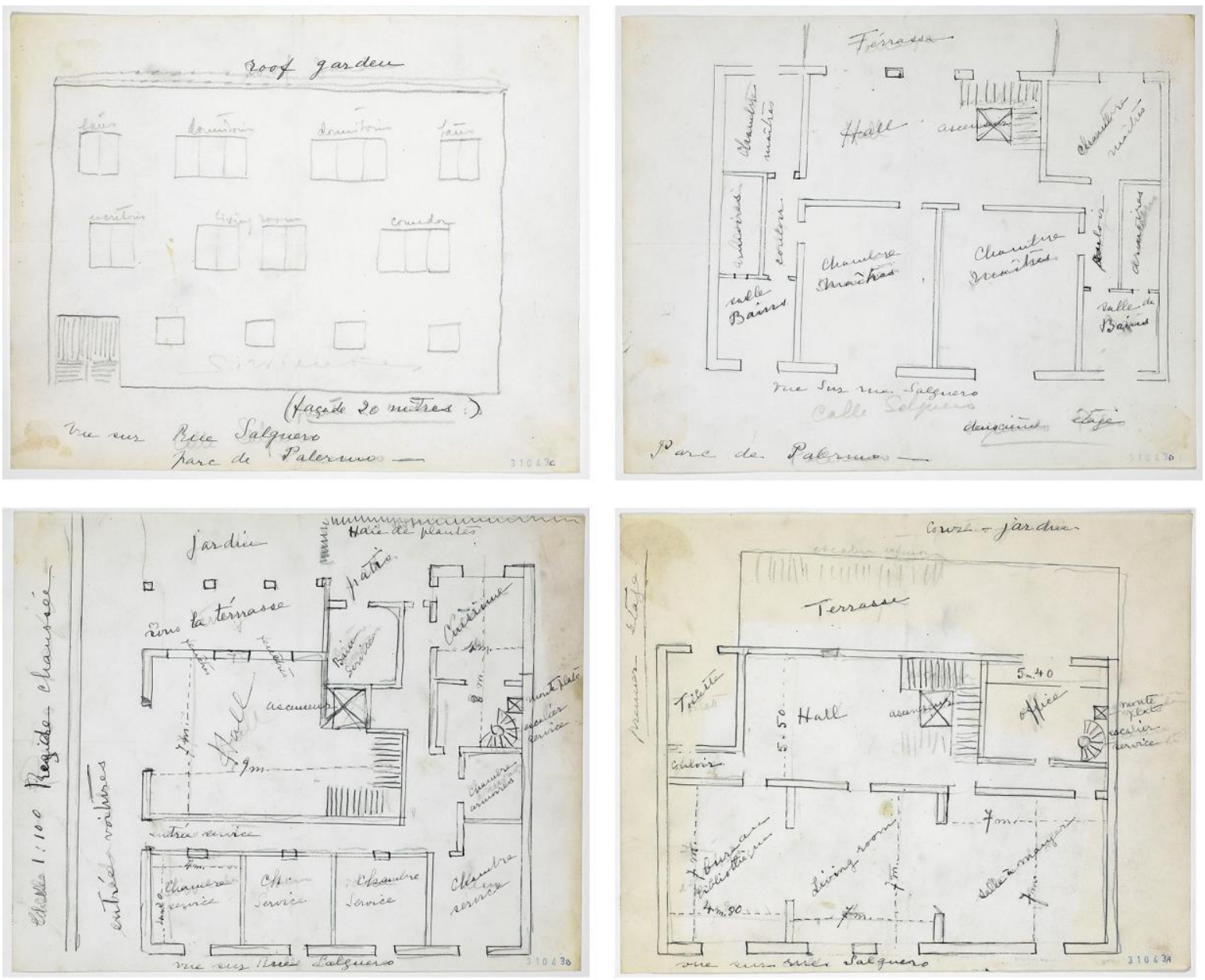

1. From left to right, top to bottom, façade towards Salguero Street, Palermo Park, Buenos Aires (FLC 31043C), second floor plan (FLC 31043D), ground floor plan (FLC 31043B), first floor plan (FLC 31043A).

\footnotetext{
${ }^{13}$ Countess Cuevas de Vera was very explicit with the specific type of openings that would be required for the house: "Pourriez vous d'après les plans, et en vous tenant à set autre genre de fenêtre, lui faire un projet de maison?," dossier Vera, FLC I1-17-1-005, August 27, 1928.

14 “...qui serait naturellement construit par son architecte avec les éléments du pays [?]," dossier Vera, FLC I1-17-1-1, August 27, 1928.
} 


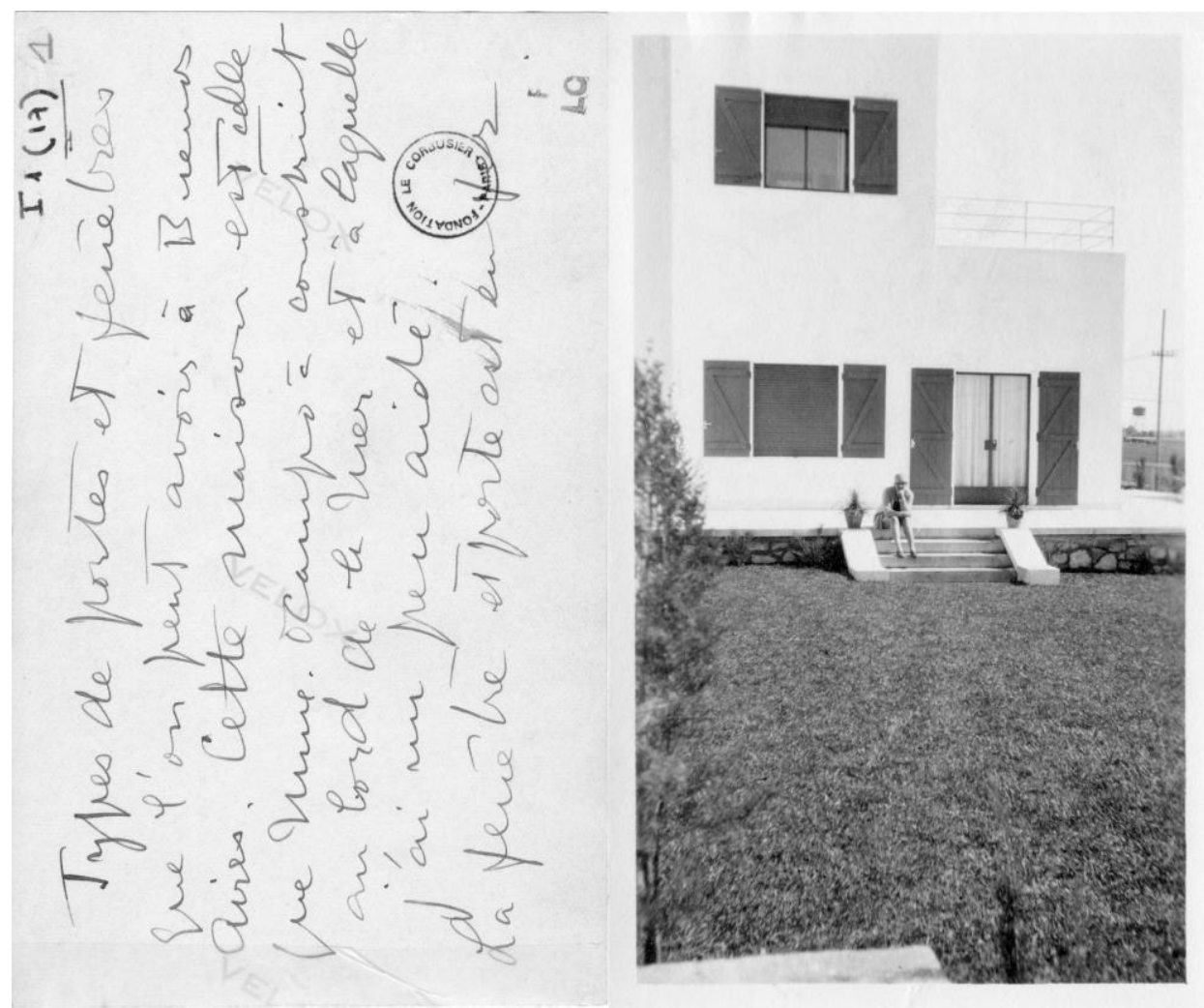

2. "Types de portes et fenêtres que l'on peut avoirs à Buenos Aires. Cette maison este elle que Mme. Ocampo a construit au bord de la Mer et a laquelle J'ai un peu aidé. La fenêtre et port est en fer," dossier Vera, FLC I1-17-1-001; FLC I1-17-1-002, August 27, 1928.

The situation changed radically upon receiving the third letter from September 6, 1928 in which Countess de Vera explained the work opportunities at the Côte Basque, a place she knew well and from which she was negotiating the project. This was not the first time Le Corbusier had been tempted to travel to the Côte Basque. Two years earlier, in March 1926, Le Corbusier had arranged a meeting in Guéthary, 10 kms. towards the south of Anglet [Fig. 3]. ${ }^{15}$ The meeting was to discuss the project of the Villa Meyer he was going to build in Paris. However, in the end, the encounter at the Meyer's summerhouse never took place, similarly to how he never received the expected written responses from the subsequent design versions he submitted in August 1925, October 1925, April 1926 and June 1926. A split existing between Madame Meyer, the client commissioning, negotiating -and potentially inhabiting- the villa, and Madame Hirtz, the rich mother who would pay for it, ${ }^{16}$ pervaded and tightened the entire relationship with the architect during the development of this earlier project. Le Corbusier, in his own words, suffered quite a bit while designing this villa, comparing himself to an "expectant father," since, according to him, "a house which remains on paper [was] a stillbirth." 17 One even may say that it was the split between the promoter-mother and the commissioning-and-inhabiting-daughter, which impeded the project to succeed.

\footnotetext{
${ }^{15}$ FLC F3-4-3-018, Carnet de Notes. 3 02/1926 - 06/1926. At least there are notes regarding the Meyers on seven spreads : FLC F3-4-3-003, F3-4-3-017, F3-4-3-018, F3-4-3-020, F3-4-3-026, F3-4-3-030, F3-4-3-048.

${ }^{16}$ Tim Benton explains this fact in "Villa Meyer (and Ocampo Project)," in Benton, The Villas of Le Corbusier and Pierre Jeanneret 1920-1930, Birkhäuser, Basel-Boston-Berlin, 2007, pp. 139-147. The diary entries, from Carnet de Notes. 3 02/1926 - 06/1926, show the name of the Hirtz at least three times: FLC F3-4-3-003, F3-4-3-030, F3-4-3-048.

17 "Une maison qui reste sur le papier est une fausse couche. Quand je vous dis que véritablement mes fibres de père souffrent.” (H3-01-17), quoted in Tim Benton, “1925. Villa Meyer. Neuilly-sur-Seine, France,” in Le Corbusier Plans, 2005.
} 


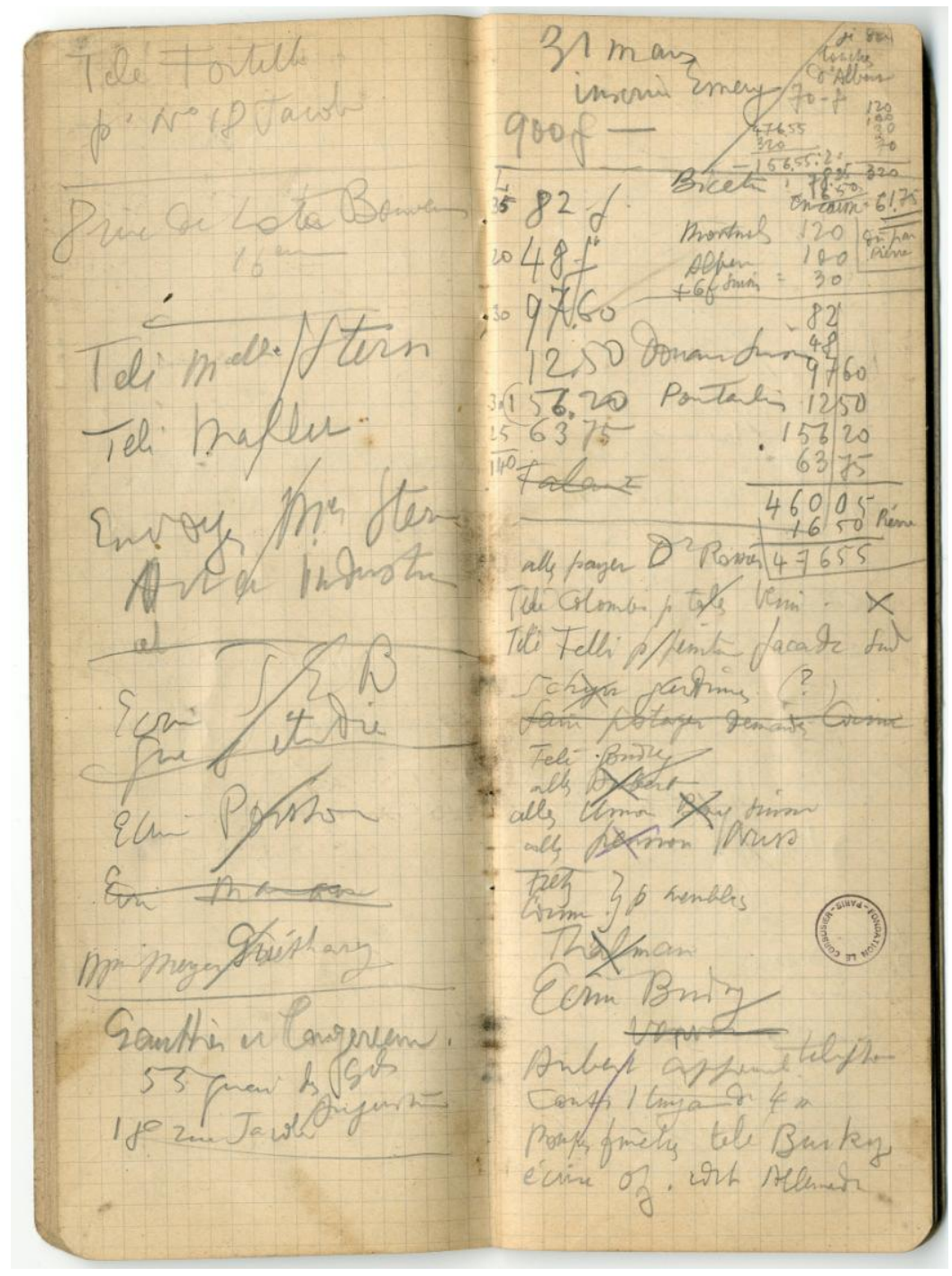

3. Inscription on the left page "Mme. Meyer, Guéthary." FLC F3-4-3-018, Carnet de Notes 3 02/1926-06/1926.

A comparable split existed in the Villa Ocampo project from the outset. While Madame Ocampo, the promoter of the project, would also be the inhabitant of the house in Buenos Aires, the project was negotiated by another person, and most importantly, from another place. Writing from Anglet, at the Côte Basque, and foregrounding the opportunities of an unspoilt area where to build anew, Countess de Vera must have awakened Le Corbusier's interest and eagerness to build outside Paris. It may be worth remembering that beyond the works he built in his hometown in Switzerland and a few exceptions such as the Villa "Le Lac" in Corseaux (1923), the Quartiers Modernes Frugés in Pessac (1924), the Maison Guiette in Antwerp (1926), and the two Maisons du Weissenhof in Stuttgart (1927), all of Le Corbusier's built work was located in Paris and its environs at that time.

Nevertheless, the existing split under the very conditions of the commission must have also awakened the memory of a recently failed project, or in other words, must have set off an alarm as to the insecure nature of this project. It is easy to understand then that with the idea in mind of trying to conquer a new market, Le Corbusier decided to send a project; but not a project designed ad-hoc. The assessment of the risks involved in this extraordinary commission likely led him to try to capitalize on a previous project he considered to be of a similar nature. This might be one of the reasons why Le Corbusier and Pierre Jeanneret submitted an updated project to the third they had prepared, two years before, for the Villa Meyer [Fig. 4, 5] 


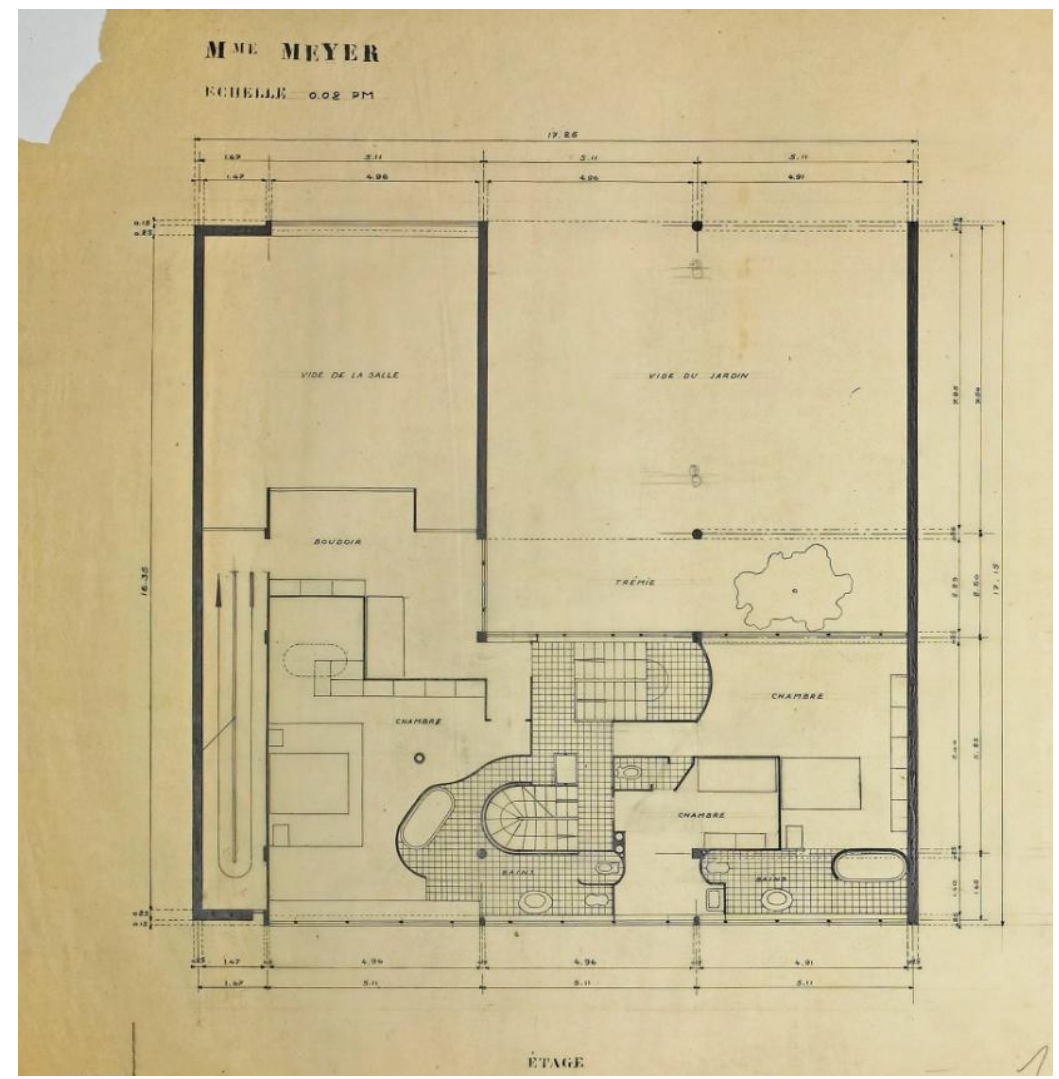

4. Villa Meyer, third project, April 1926, first floor. FLC 10370.

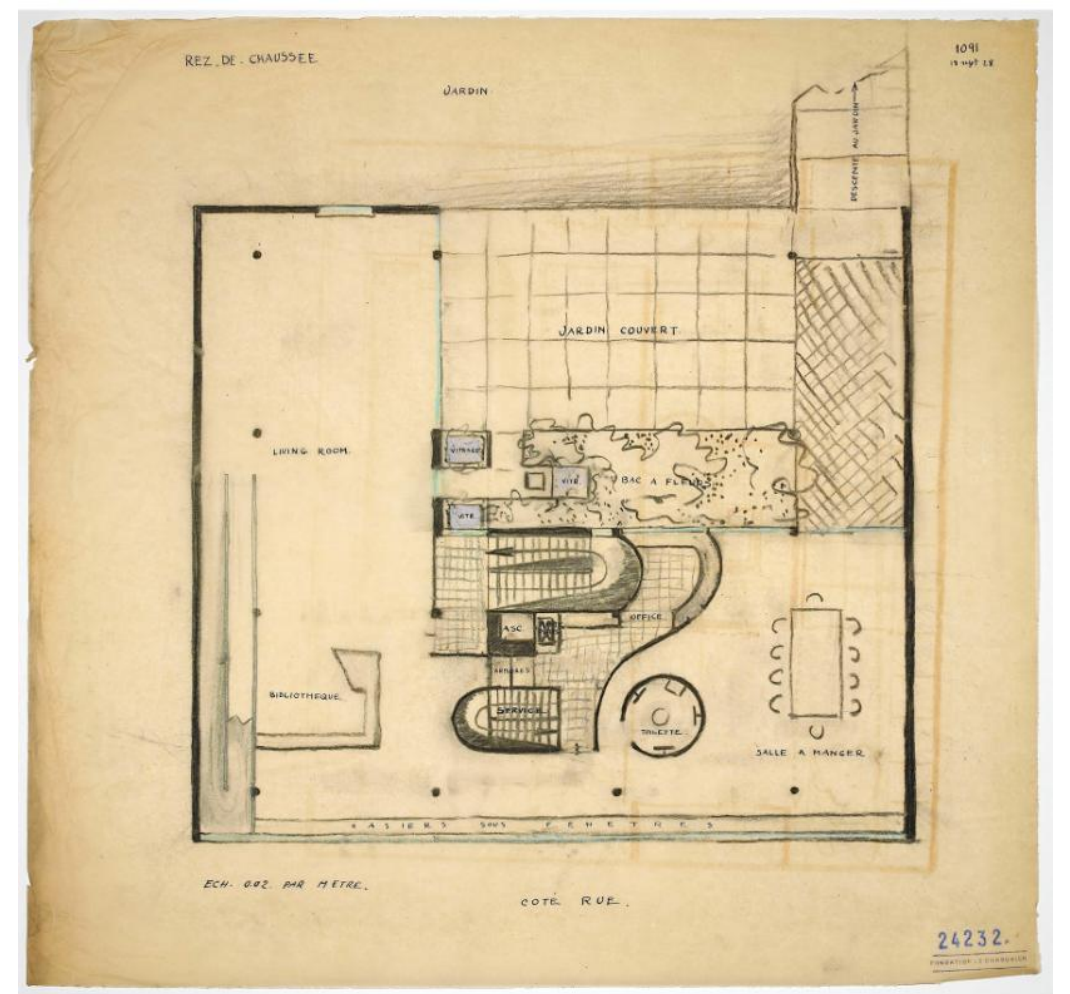

5. Villa Ocampo, September 1928. FLC 24232A. 


\section{3. "R-e-g-i-o-n-a-l-i-s-m!" and the outsiders}

In the letter from September 6, 1928, sent from Villa Delphine in Anglet, Countess de Vera warned Le Corbusier about the pervading Basque style of the region. Le Corbusier had already shown his rejection to regionalism in 1923, since for him it showed quite an opposite state of mind to the one needed for building, living, and conceiving mass-production. Le Corbusier lamented seeing that "the mass-production state of mind was still hateful for both architects and inhabitants," and claimed that "[they had] just gotten as far, all breathless, as $r$ e-g-i-o-n-a-l-i-s-m! Phew!," and that "the funniest thing [was] the devastation of the invaded lands along the way. "18

A few years later, in 1936, Le Corbusier lamented seeing that the regionalism of the Basses-Pyrénées, which only responded to linguistic codes, had been spread towards the north, up to the Bay of Arcachon in the Gironde, an area he very much loved and in which he had vacationed for years. "I like wooden houses because they are honest: both spiritually and in construction. Le Piquey is ruined! I knew it before the roads and the builders. The lagoon, governed by the thirteen-hour rhythm of the tides - a truly cosmic rhythm-breeds constant diversity and infinite combinations. Now the houses have become "Basques" with false beams in painted cement and fake wood!...I do believe that if the land had been in the hands of savages, the other half-the lagoon-would have been saved. Where the hell to find something true...?",19

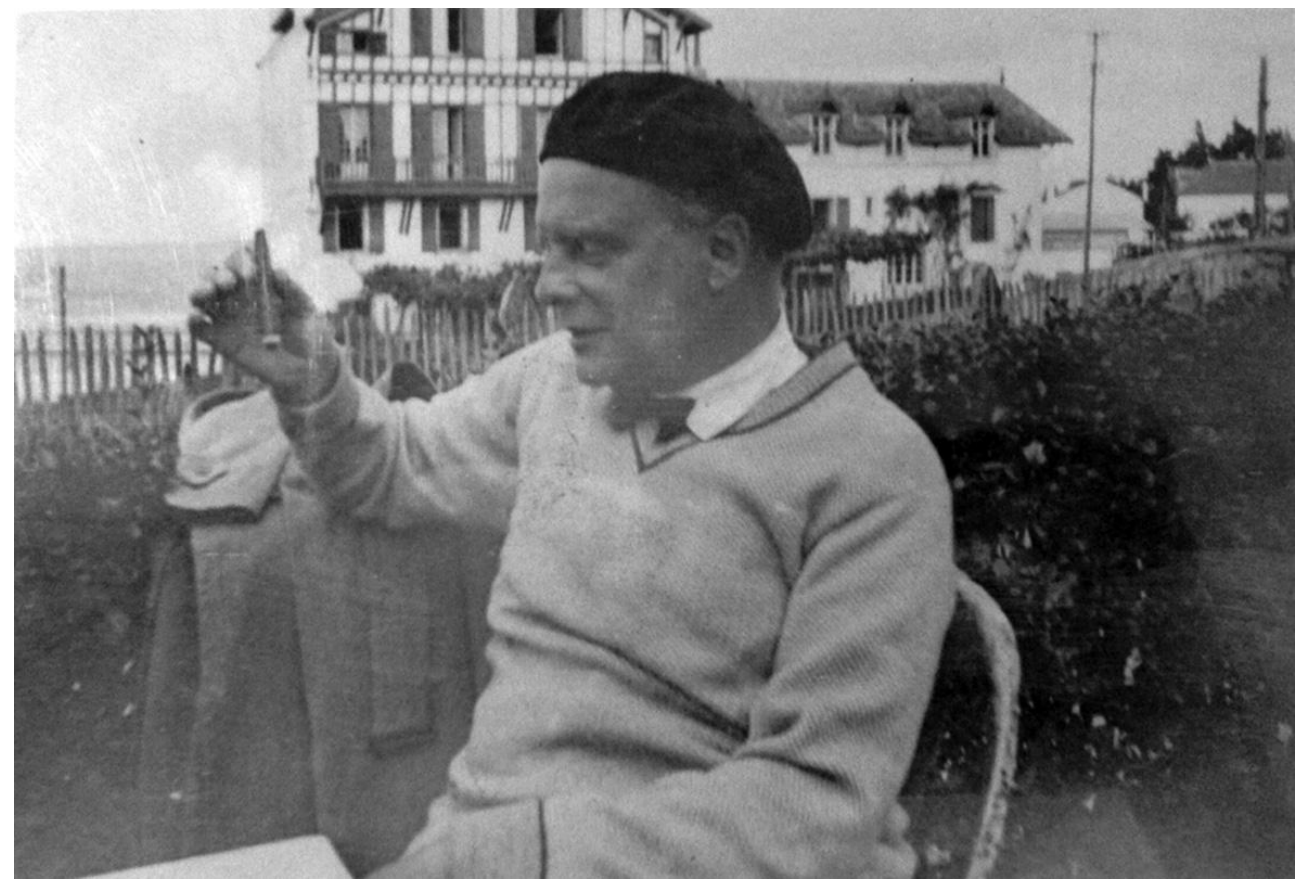

6. Typical Basque houses in Guéthary. Paul Klee at the Côte Basque, August 1929.

\footnotetext{
18 "L'état d'esprit de la série est haïssable aux architects et aux habitants...on en arrive justement, et tout essoufflé, au r-é-gi-o-n-a-1-i-s-m-e! Ouf! Et le plus comique, c'est la devastation des pays envahis qui nous y conduit," in Le Corbusier, Vers une architecture, Paris: Flammarion, 2005, p. 189 (1923). Translated as "Mass-Production Housing," in Towards an Architecture, Los Angeles: Getty Research Institute, 2008, p. 255.

19 This is a note that Le Corbusier wrote in September 1936 in the visitor's book of the Grand Hôtel Chantecler, FLC E2-8109, quoted in Tim Benton, "Atlantic Coast: Nature as Inspiration," in Cohen (ed.), Le Corbusier. An Atlas of Modern Landscapes, pp. 165-166.
} 
The area of the Basses-Pyrénées, right on the Spanish border, which Countess de Vera was presenting as a new area of opportunities to Le Corbusier, was particularly difficult to intervene [Fig. 6]. The local architects did not succeed in stepping back from regionalism, as was the case of Henri Godbarge, who extoled the Basque style and was the main theorist of the neo-Basque regionalist movement after WWI, publishing Arts Basques Anciens et Modernes. Origine, Evolution in 1931. Joseph Hiriart, a quite popular architect who had designed La Maitrise Pavilion (the pavilion of Galeries Lafayette), at the Exposition des Arts Décoratifs (1925), built in 1926 both a house in a very traditional Basque style and another one that would become a gem of Art Deco. Both houses, constructed precisely on Bordegain, Ciboure, the same mountain between St. Jean de Luz and Hendaye that Countess de Vera was referring to, adopted Basque names with eloquent meanings, as is typical in the region: "Villa Lehen-Tokia" (which means "first place") and "Villa Leïhorra," (which means "refuge in land"). ${ }^{20}$ In 1928, Hiriart built the Hôtel-Casino la "Roseraie" in Ilbarritz, Bidart, moving towards modern spatial arrangements, but still keeping a substantial amount of regionalist features on the roof.

Another extreme case was that of William Marcel, a regionalist architect from Bayonne, who in 1923 received the commission to build a hotel-casino on the terrace of the old bathhouse of Saint-Jean-de-Luz by Juste Lisch. The project needed to make a strong statement in order to convince the visitors of the Côte Basque arriving from Paris, to travel a few more kilometers towards Spain (from Biarritz to Saint-Jean-de-Luz). Marcel proposed a hotel of 140 rooms with a casino, a swimming-pool, a garage, and a series of covered galleries, forming a square towards its center, in an ostentatious neo-Basque style that was quite controversial at the time and finally was not built [Fig. 7].

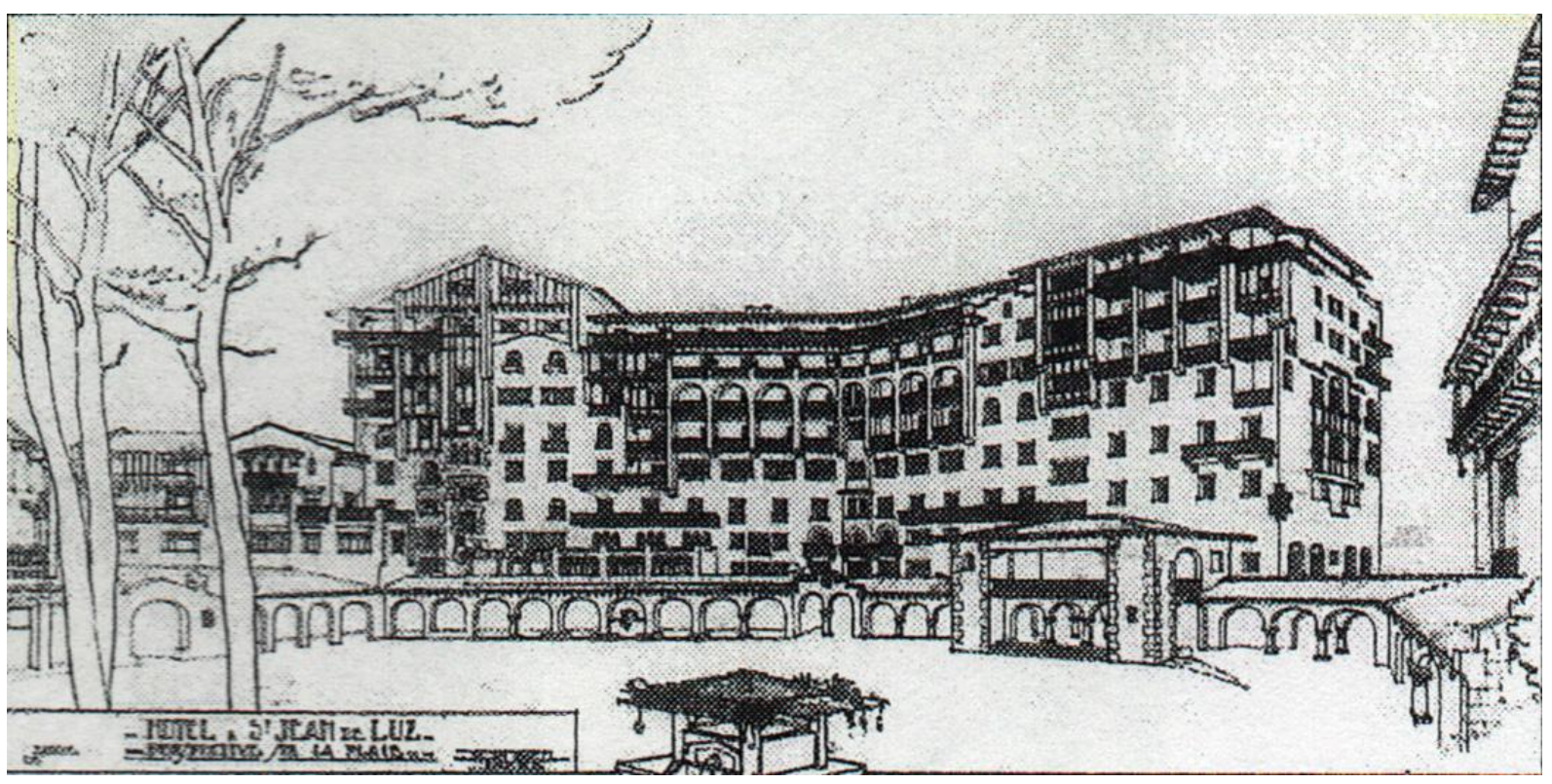

7. Hôtel-Casino La Pergola, Saint-Jean-de-Luz. Project by William Marcel, c1924.

The outsiders however, who visited and were impacted by the built environment of the area, were able to surpass the linguistic features of Basque regionalism, as is attested by many of the works they created during or right after their stays. The many artists of the French and German avant-gardes that spent their holidays in the area were not trapped by the colored timber, the protruding eaves and the inclined roofs, and produced instead artistic works of modern compositional order.

\footnotetext{
${ }^{20}$ I would like to thank here Michel Sarlangue who directed my attention to the development of Bordegain and to these houses.
} 
In 1926, Man Ray had been captivated by a classical villa on the top a cliff in Bidart, which had been built by a Rumanian aristocrat in 1912 and had been given the Basque name "Emak Bakia" ("leave me alone"). Ray was so fascinated by this place that he would convert the Basque expression into one of his artistic mottos and would even shoot a experimental film under the same name in order to claim the artistic freedom of film [Fig. 8]. ${ }^{21}$ In 1929, Paul Klee spent a long vacation with his wife Lilly and his son, Felix, in "Villa Louisiana," another single family house in the Basque style, less than 50 meters away from "Emak Bakia." "Garden House" [Fig. 9], the oil-painting Klee created shortly after, blended the color of the timber and the windows-and-shutters with

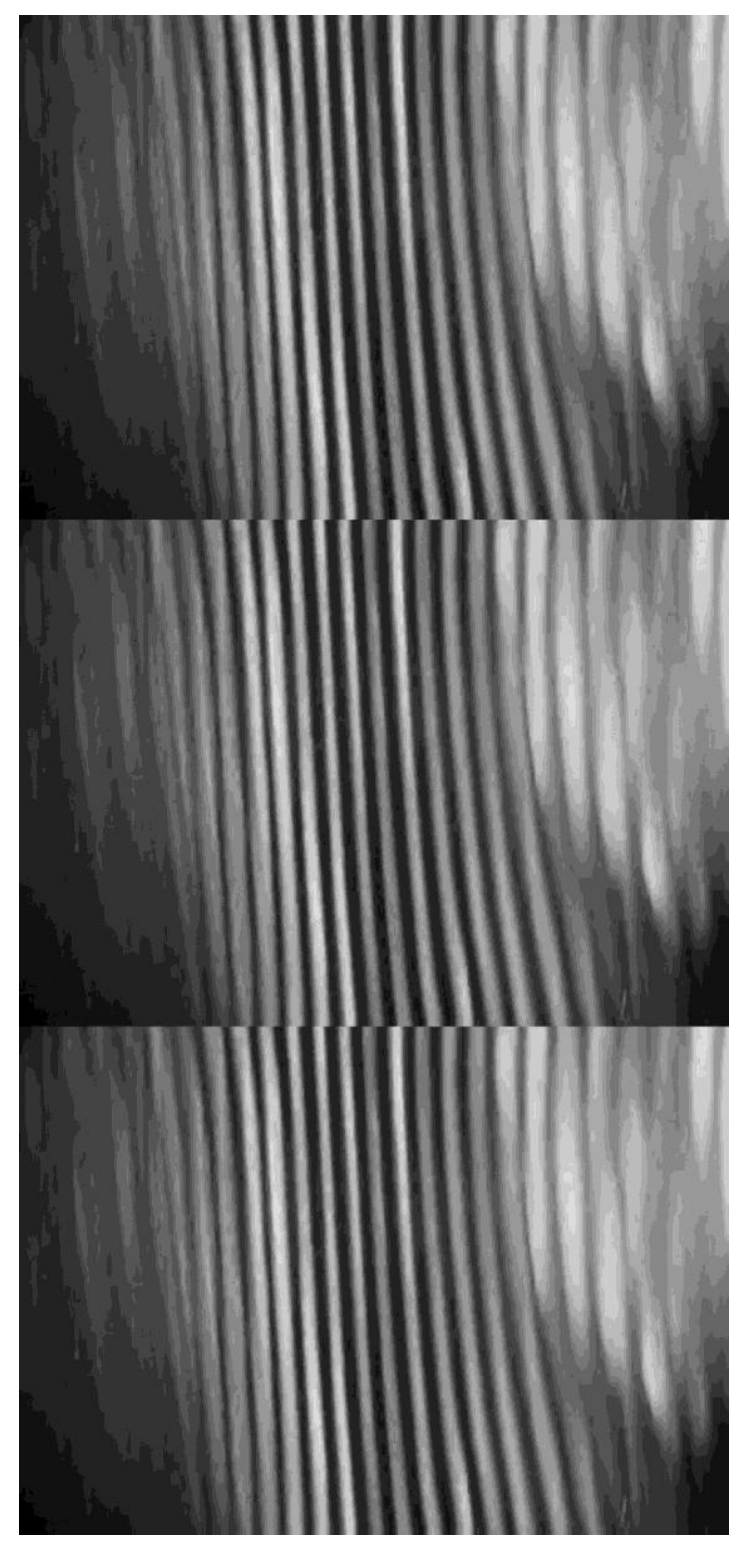

8. Still from Man Ray, Emak Bakia [Leave me alone] 1926, 3’21'’.

\footnotetext{
${ }^{21}$ Only three shots of the Villa in Guéthary and its settings exist in Man Ray's documentary film: a close-up of its front door, two columns of a wall-opening towards the sea, and a view of the nearby coast. Following these hints and the assistance of other informers, Oskar Alegría decided to undertake a quest on foot to find it, which lead to the film "Emak Bakia Baita!," the house of Emak Bakia. See: http://emakbakiafilms.com/en/
} 


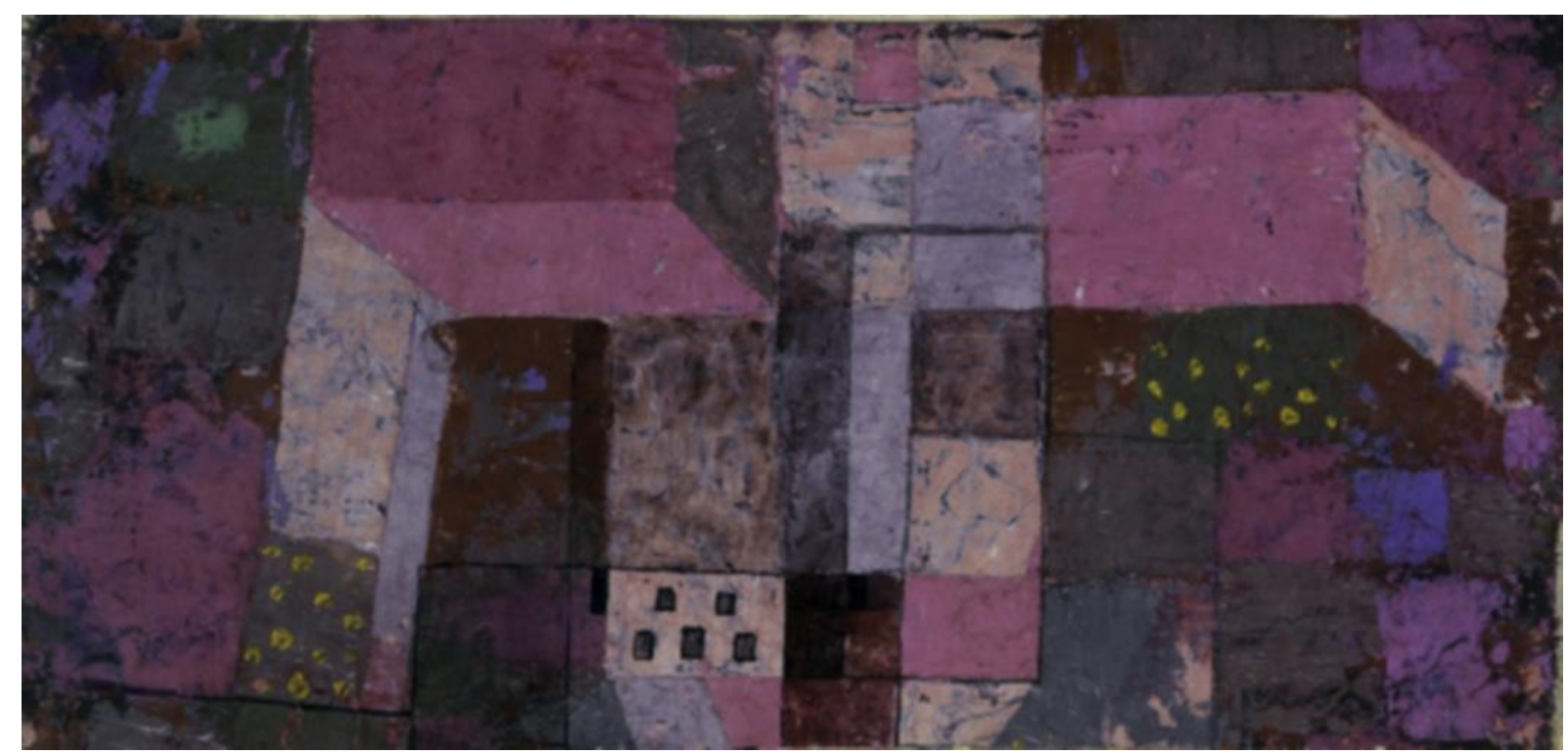

9. Paul Klee, Garden House [Gartenhaus], 1929, 347. Oil-colour and watercolour on muslin on card (21 x $42 \mathrm{~cm})$.

that of the garden, creating an abstract reddish-purple landscape in which five openings are organized in the form of a herringbone. ${ }^{22}$ During the same summer of 1929, the everyday environment for Vasily Kandinsky's vacation was the classical portico of composed columns surrounding the Hotel Euskalduna (1912), a monumental complex of regional inspiration by Henry Martinet that stands on the main avenue of HendayePlage [Fig. 10]. However, Kandinsky did not bring any of the regionalist features of those porticos to the oilpaintings he created in the autumn of 1929, but created many structural porticos of modern spatial composition such as "Scarcely Colored Structure," "Jocular Sounds" or "Horizontal Blue".

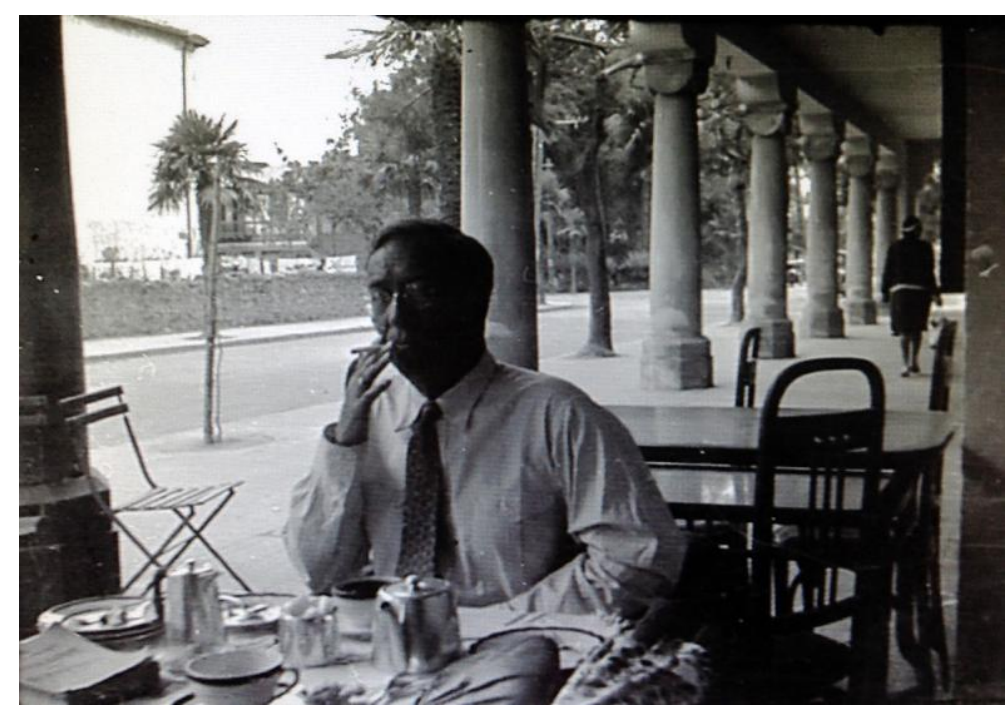

10. Arcades of the Hotel Euskalduna in Hendaye-Plage. Vasily Kandinsky during breakfast, summer 1929 (n. 947).

\footnotetext{
22 "In the Garden of Villa Louisiana" (1929, 246), another drawing created during the vacation of the Klees in the BassesPyrénées confirms the name of the house where they spent the summer of 1929. Zentrum Paul Klee, Bern.

${ }^{23}$ There are more than twenty photographs showing the everyday life of Kandinsky in Hendaye-Plage during the summer of 1929. The elements of Basque regionalism are pretty apparent in the background of those photographs. Archives at Fonds Kandinsky, MNAM-CCI, Centre Pompidou.
} 
During his long holiday on the Còte Basque, Kandinsky even visited and bought several postcards of the Casino La Pergola by Mallet-Stevens, the real battle winner, among the outsiders, able to surpass regionalism [Fig. 11]. In fact, Mallet-Stevens managed to develop the project and to build the Hôtel-Casino starting from the original and unsuccessful six-floor structure previously constructed by Marcel. ${ }^{24}$ With materials that were new for the region, such as the steel and concrete that were otherwise very attached to the French ferro-concrete tradition, and relying on colors that went beyond the typical red and green of the Espelette pepper, Mallet-Stevens managed to create a quite balanced modern work of architecture. The building was immense, a size Le Corbusier was still dreaming of developing at that time. It was a small city in itself, with a multifunctional program that included a hotel, a casino, restaurants, boutiques, and many different other entertainments, all organized compactly in the form of a strange ocean liner that seemed to have just landed on the beach. However, despite its huge volume, a series of thinner, more slender elements and shapes placed asymmetrically were able to endow the building with an image of lightness that entered into a dialogue with the ephemeral fabric huts of the beach [Fig. 12].

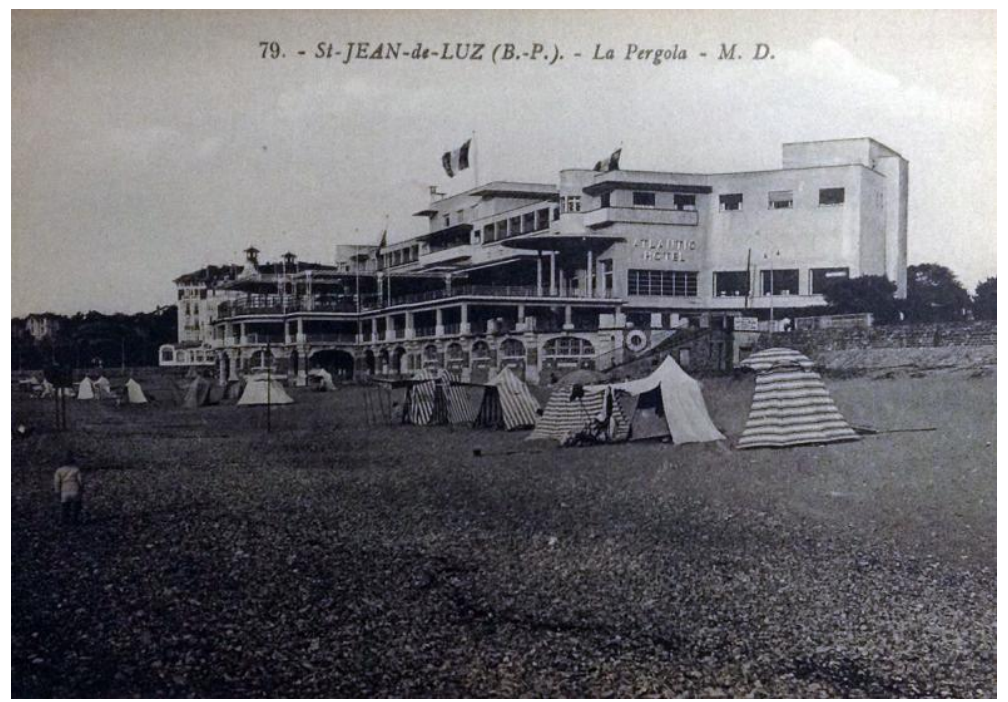

11. Postcard of Casino La Pergola in Saint-Jean-de-Luz, bought by Vasily Kandinsky, summer 1929.

Mallet-Stevens had been much more successful at the Paris Exhibition of 1925 than Le Corbusier and his L'Esprit Nouveau Pavilion, with the bold concrete trees of its garden and the daring hall of his transportation pavilion suspended on only two supports. But the project that truly led Mallet-Stevens to fame was the opening of the Rue Mallet-Stevens he built in Auteil, Paris, in 1927, barely 150 meters away from the houses Le Corbusier had built in the same Parisian neighborhood, and which, coincidentally, Countess de Vera had requested to see in her first letter. The impact the work of Mallet-Stevens caused across France was precisely the reason why the developers of the Casino La Pergola in Saint-Jean-de-Luz called him in the autumn of 1927, so that he would engage with a commission they had been unsuccessfully trying to develop for four years. ${ }^{25}$ MalletStevens succeeded to finish the building in only one year.

\footnotetext{
${ }^{24}$ Lyonnet, Jean Pierre (Ed.), “L’Affaire du Casino de Saint-Jean-de-Luz,” in Robert Mallet-Stevens Architecte, Paris: Éditions 15, square de Vergennes, 2005, pp. 188-198.

25 "Casino de Saint-Jean-de-Luz. 1927-1928," in Robert Mallet-Stevens: l'oeuvre complète [Ouvrage publié à l'occasion de l'exposition présentée au centre Pompidou, galerie 2, du 27 avril au 29 août 2005], Paris: Centre Pompidou, 2005, pp. 142145.
} 


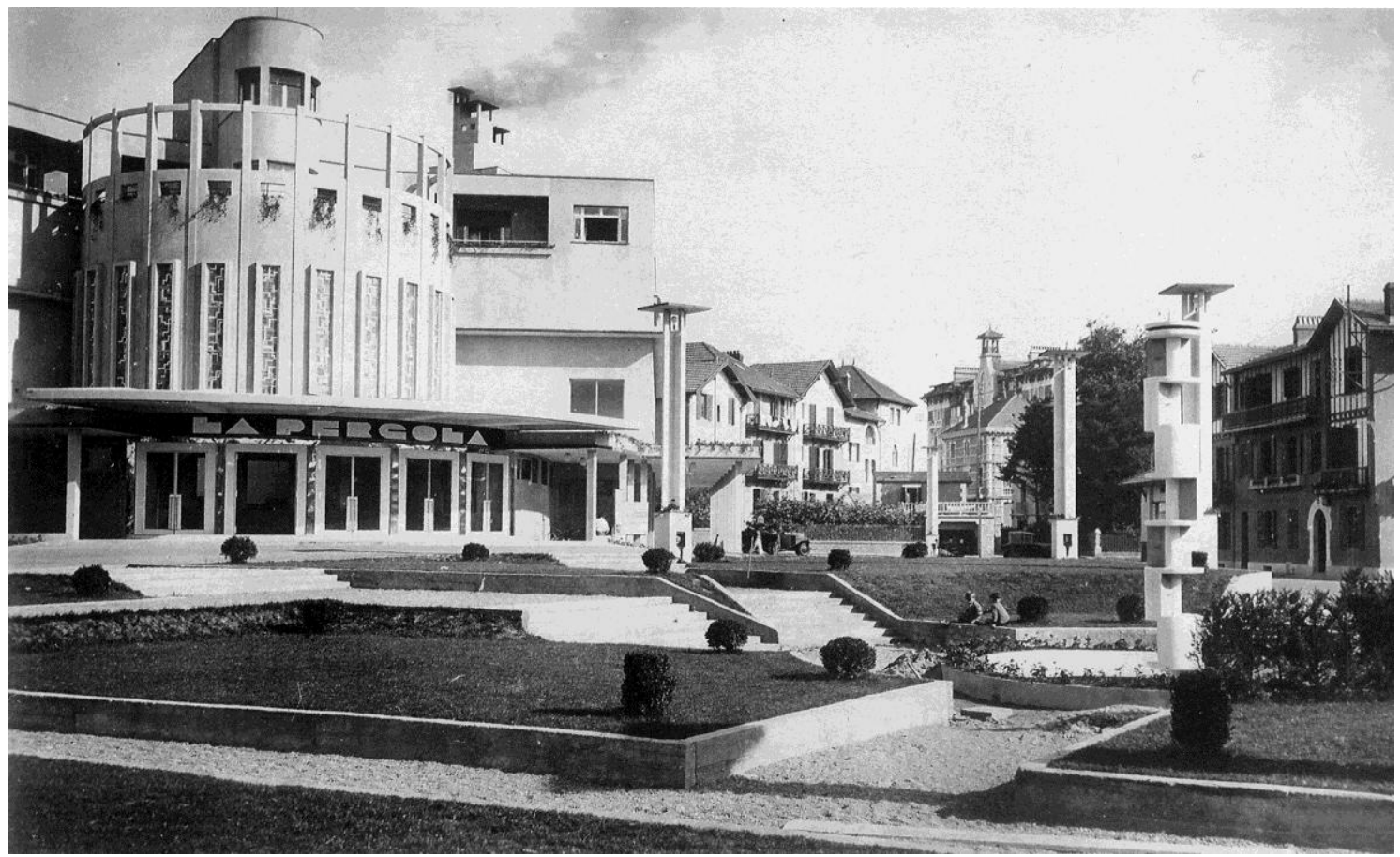

12. Robert Mallet-Stevens. View of Casino La Pergola from the street entrance, 1928.

In terms of professional accomplishment we may say that Mallet-Stevens was far beyond Le Corbusier at that time. Moreover, Le Corbusier was conscious of the challenge implied by interventions on areas of such strong cultural and linguistic identity, as is the Côte Basque. Therefore, it must have been painful for him to realize that his most direct competitor in France had not only carried out this ambitious endeavor successfully, but the realization of this work had also allowed him to monopolize the market of a rising clientele of luxury single family houses in the southwest of France. This might be another motivation behind Le Corbusier's desire to get in on this market, causing him to send a project to Biarritz.

\section{4. "I exist in life only if I can see"}

Le Corbusier sent off the set of drawings he prepared for the Villa Ocampo on September 18, 1928, but the project arrived too late and never took hold. ${ }^{26}$ However, through the debt he created on the part of Victoria Ocampo, Le Corbusier achieved something probably more important than a commission. Since, as it is wellknown, Victoria Ocampo would play a key role in the organization of his lectures in Argentina in October 1929.

"The plan is pure, made exactly in accordance with needs," said Le Corbusier in the lecture entitled "The Plan of the Modern House" referring to the Villa Savoye, and foregrounding the importance of the accommodation of function over the response to site. "[The plan] is in its right place in the rural landscape of Poissy," he continued [Fig. 13]. "But in Biarritz, it would be magnificent. If the view is elsewhere, on another side, if the orientation is different, the hanging garden would simply be turned around. This same house, I should set [sic] down in a corner of the beautiful Argentine countryside. "27

\footnotetext{
26 "Je regrette infiniment que votre projet se sot pas réalisables pur cette tois ici...[Madame Ocampo] va donc faire construire le plan que je vous ai envoyé et elle en est désolée, car elle n'en est pas satisfaite," dossier Vera, FLC I1-17-12, September 29, 1928.

27 "Le plan est pur, fait au plus exact des besoins. Il este à sa juste place dans l'agreste paysage de Poissy. Mais à Biarritz, il serait magnifique. Si la vue est ailleurs, d'un autre côté, ou si l'orientation est différente, le jardin suspend sera tout
} 


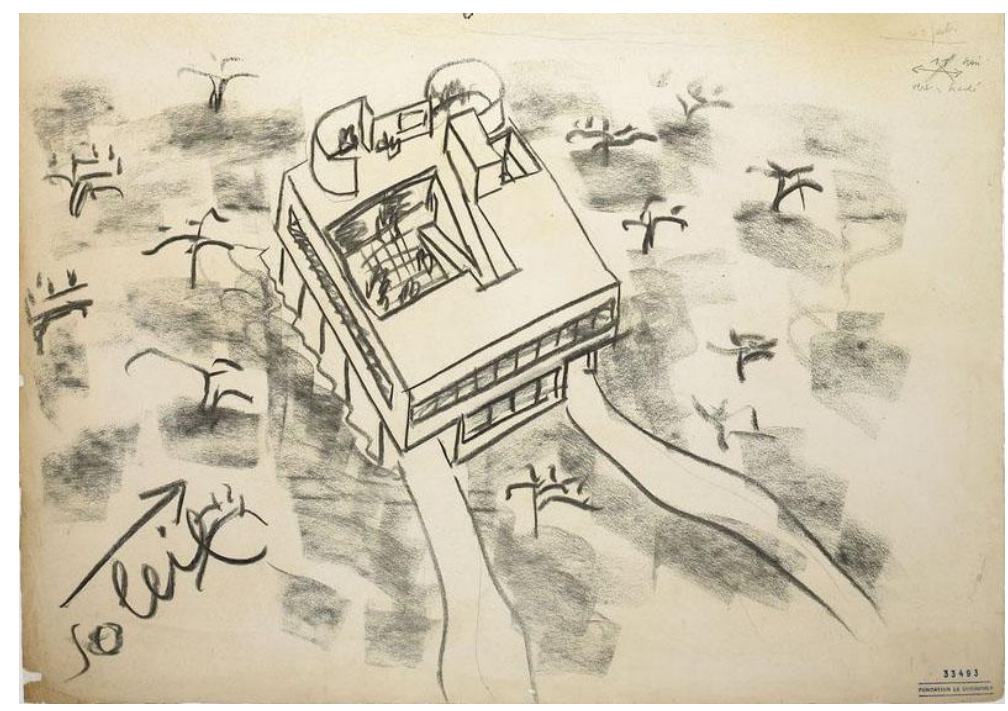

13. Drawing by Le Corbusier during the lecture "The Plan of the Modern House," October 11, 1929. FLC 33493.

This indifference for the siting of a project Le Corbusier seemed to show when he recognized that a house designed for Paris could equally fit in Biarritz or Argentina, is the same he had revealed one year earlier, in September 1928, when he submitted an updated version of the Villa Meyer for a project meant to be built in Buenos Aires. However, this apparent lack of engagement with place should not be seen as a stance toward nonspecificity. As Barry Bergdoll has proposed, Le Corbusier's buildings were "types of viewing devices" for the landscape beyond it. ${ }^{28}$ Thus, we can understand that Le Corbusier was offering a different kind of relationship with site, which did not have to do with the creation of an interviewing interior-exterior relationship; rather, with the connection between the projects and the distant surroundings they overlooked. The importance Le Corbusier gave to these "viewing devices," and his conviction that modern dwelling was about seeing, is confirmed by his famous aphorism, "I exist in life only if I can see," ${ }^{29}$ included in the "American Prologue" he wrote to accompany the ten lectures of Argentina from October 1929.

The fact that Le Corbusier had conceived the Villa Meyer as a viewing device for Saint James Park in Paris, and probably had not been very concerned by achieving a particular engagement with Avenue de Madrid, is clearly revealed in the perspectives he created for the third version of the project. The last perspective of the seven views he put together shows clearly how he arranged his architecture as a frame through which to look [Fig. 14]. ${ }^{30}$ This creative approach produced a constant play between the small scale of the everyday life objects in the

simplement modifié. Cette même maison, je vais l'implanter dans un coin de belle champagne argentine; nous aurons vingt maisons surgissant des hautes herbes d'un verger où continueront de paître les vaches." Le Corbusier, "Le Plan de la Maison Moderne," in Précisions sur un état présent de l'architecture et de l'urbanisme, Paris: Crès, 1930, p. 138.

${ }^{28}$ Berdgdoll, Barry, "From International to Territory: The Project of an Atlas," in Cohen, Jean-Louis, An Atlas of Modern Landscapes, pp. 18-21.

29 “Je n'existe dans la vie qu'à condition de voir," in Précisions sur un état présent de l'architecture et de l'urbanisme, Paris: Crès, 1930, p. 8.

${ }^{30}$ Another coincidence is that Le Corbusier met Mallet-Stevens in April 1926, the same week in which he was drawing the perspectives of the third version of the Villa Meyer. Le Corbusier's diary on Monday April 12, 1926, writes a reminder about some drawings of the Villa Meyer, "Dessins perspec. Meyer," and a few lines below mark a meeting at 7 o'clock with Mallet-Stevens on Tuesday April 13, 1926. These drawings must have been those from the third version of the Villa Meyer, since this third project was sent off on April 24. See FLC F3-4-4-020. 
foreground and the larger scale of the geographical features in the background. In such a spatial relationship, the opening was the main architectural element that made his buildings site-specific. ${ }^{31}$

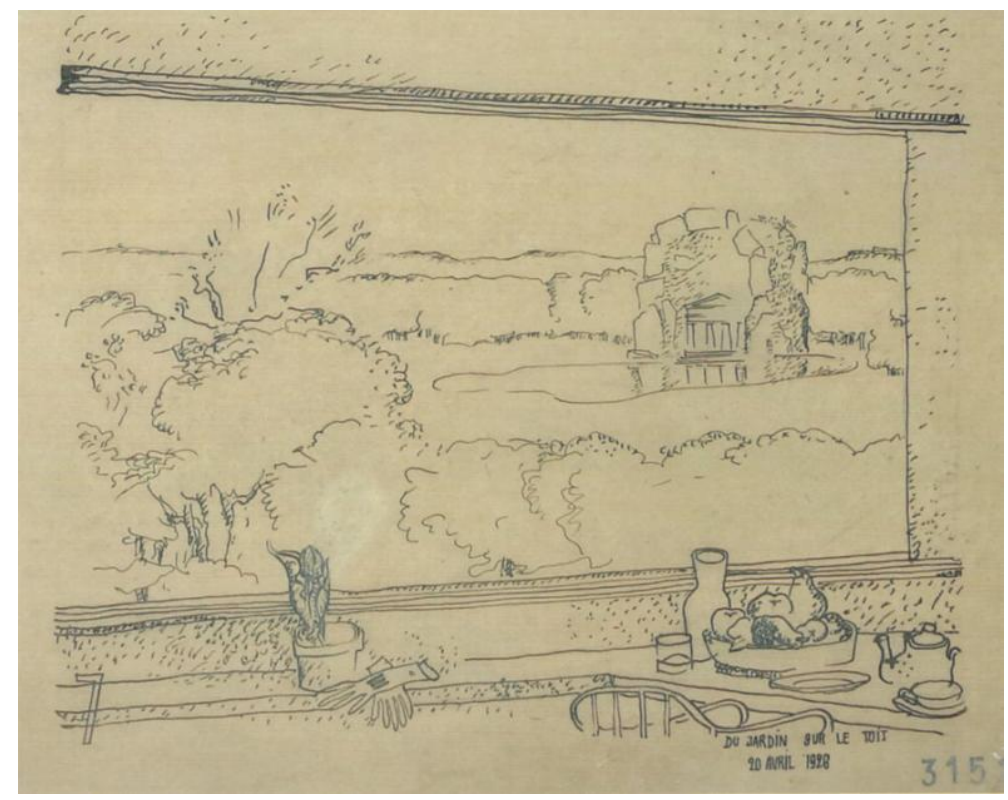

14. Villa Meyer, seventh perspective of the third project, April 1926. FLC 31514.

In a similar way, it is very probable that Le Corbusier conceived the Villa Ocampo as a viewing device for the area around Park of Palermo in Buenos Aires. However, as he did not know the site, the opening he proposed was a more abstract cube of air and which could offer Victoria Ocampo through spatial experience a different kind of modern awareness. It should not be forgotten that Countess de Vera had explicitly asked Le Corbusier whether it would be possible to do something of a similar nature to the Villa in Garches, towards the side of the garden. Le Corbusier drew this cube of air, which included a mezzanine along the side of a double-height terrace, in the last perspective of the three he put together for the project [Fig. 15].

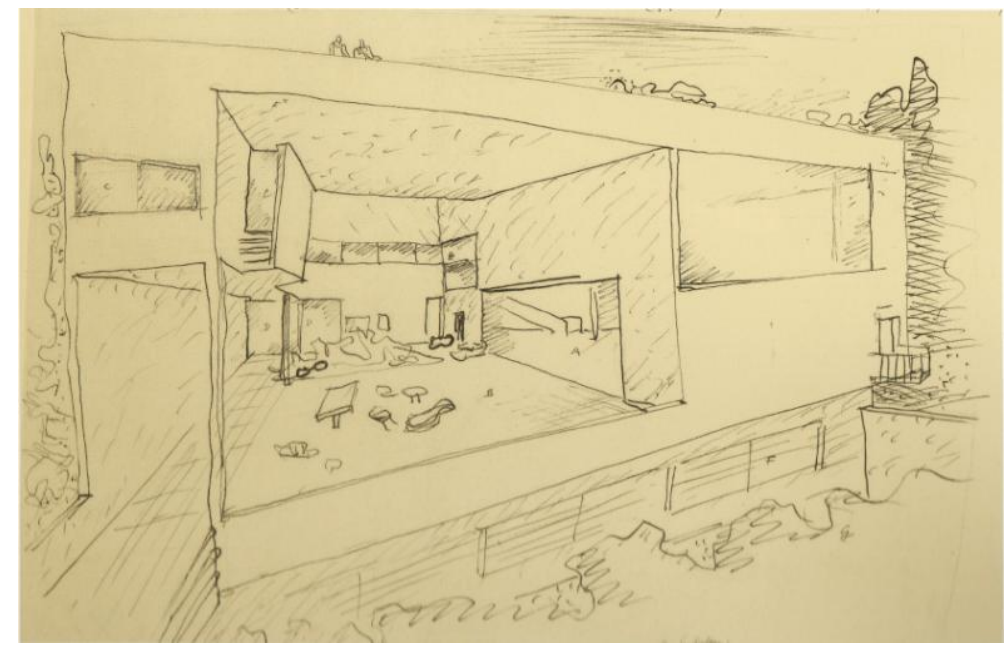

15. Villa Ocampo, perspective of garden front, final project, September 18, 1928. FLC 24235.

\footnotetext{
${ }^{31}$ See also Martínez de Guereñu, Laura, "Zeharka begiratzeko markoak: 'Ikustearen baldintza bakarrarekin existitzen naiz bizitza honetan," in Aldiri, Arkitektura eta abar, nº 9 (Ttipi), Bilbao, 2012, pp. 14-19.
} 
As Jean-Louis Cohen has stated, the more generic projects of Le Corbusier, capable of being inserted into multiple locations, were designed as "camera lucidae" to enable distant observation. ${ }^{32}$ Hence, the hanging gardens, window openings with sills or abstract cubes of air of these projects call all be considered "viewing" architectural elements that allowed Le Corbusier to engage with the landscape no matter the specific site in which they were inserted.

In July 1930, almost one year after his trip to South America, Le Corbusier would finally visit Biarritz en route from Spain to Paris [Fig. 16]. ${ }^{33}$

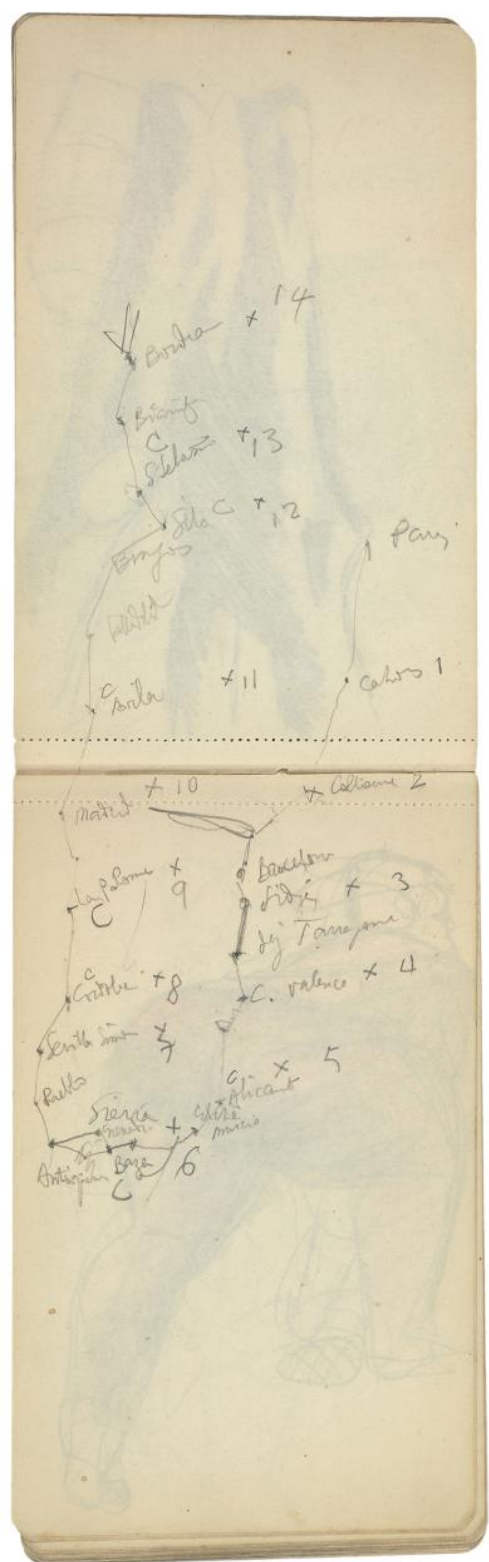

16. Scheme of the trip through Spain in July 1930, realized in Le Piquey. FLC Carnet B8-481, FLC Carnet B8-482.

\footnotetext{
${ }^{32}$ Cohen, Jean-Louis, “In the Cause of Landscape,” in Cohen, Jean-Louis, An Atlas of Modern Landscapes, pp. 23-47.

${ }^{33}$ The stop in Biarritz happened on the way back to Paris, after having traveled more than $2.800 \mathrm{kms}$ in 12 days across Spain, in Raoul La Roche's Voisin, with Fernand Léger, his brother Albers, and his cousin and partner Pierre Jeanneret. In Le Corbusier's carnets of the summer of 1930, there is a drawing of a dry tree that has a hand-written route on its back : Madrid, Ávila, Valladolid, Burgos, Silos, San Sebastián, Biarritz, Bordeux. Le Corbusier, Carnet B8. Scheme of the trip to Spain of July 1930, drawn in Le Piquey. See, Lahuerta, Juan José (Ed.), "Espagne”: carnets, Milano: Electa, 2001, p. 36.
} 
One month after the trip, on a letter to Victoria Ocampo on August 30, 1930, Le Corbusier would share his impressions of this Southern European country. The terms as well as the tone Le Corbusier employed might now serve to summarize the significance of the Villa Ocampo commission in Buenos Aires in his work and the many opportunities that were brought along with it, after his trip to South America: "Prestigious! Grandiose, distanced, human and gentile. Great souvenir."${ }^{34}$

\section{Acknowledgements}

I would like to thank Arnaud Dercelles and Delphine Studer for kindly sending digitalized material for this research from Fondation Le Corbusier, Michel Sarlangue for sharing with me different local research resources, Bárbara Pons for her help with the transcription and translation of the correspondence, and Josep Quetglas for encouraging me to write this paper. Research on Paul Klee's Papers at Zentrum Paul Klee, Bern, and on Vasily Kandinsky's Papers at the Centre Pompidou Paris, were benefited by travel subsidies from the Fritz Thyssen Foundation.

\section{Source of images}

Fig. 1. Fondation Le Corbusier. (c) FLC-ADAGP.

Fig. 2. Fondation Le Corbusier. @ FLC-ADAGP.

Fig. 3. Fondation Le Corbusier. ( ) FLC-ADAGP.

Fig. 4. Fondation Le Corbusier. ( ) FLC-ADAGP.

Fig. 5. Fondation Le Corbusier. @ FLC-ADAGP.

Fig. 6. The Norton Simon Museum Archives, Pasadena, California.

Fig. 7. Robert Mallet-Stevens Architecte, Paris: Éditions 15, 2005.

Fig. 8. MNAM-CCI, Centre Pompidou. Fonds Man Ray.

Fig. 9. Albertina, Vienna - On permanent loan from the Forberg Collection. Photo: Fotoatelier Peter Schälchli, Zürich.

Fig. 10. MNAM-CCI. Fonds Kandinsky.

Fig. 11. MNAM-CCI, Centre Pompidou. Fonds Kandinsky. VK (série 1), blank postcards.

Fig. 12. Jean-Pierre Lyonnet personal archive.

Fig. 13. Fondation Le Corbusier. @ FLC-ADAGP.

Fig. 14. Fondation Le Corbusier. @ FLC-ADAGP.

Fig. 15. Fondation Le Corbusier. @ FLC-ADAGP.

Fig. 16. Fondation Le Corbusier. @ FLC-ADAGP.

\section{Bibliography/ references}

Alegría, Oskar, Emak Bakia baita (The Search for Emak Bakia), 2012. (86 min.)

Benton, Tim, “1925. Villa Meyer. Neuilly-sur-Seine, France,” (Project 61, DVD 1), in Le Corbusier Plans, Paris: Codex Images International/ Fondation Le Corbusier, 2005.

Benton, Tim, The Villas of Le Corbusier and Pierre Jeanneret 1920-1930, Basel-Boston-Berlin : Birkhäuser, 2007.

\footnotetext{
34 “Fait le tour de l'Espagne en auto. Prestigieux! Grandiose, Lointain, humain et gentil. Grand souvenir." Dossier Victoria Ocampo, FLC E2-17-183-003. August 30, 1930.
} 
Benton, Tim "Atlantic Coast: Nature as Inspiration," in Cohen, Jean-Louis (Ed.), Le Corbusier. An Atlas of Modern Landscapes, New York: Museum of Modern Art, 2013, pp. 165-166.

Berdgdoll, Barry, "From International to Territory: The Project of an Atlas," in Cohen, Jean-Louis (Ed.), Corbusier. An Atlas of Modern Landscapes, New York: Museum of Modern Art, 2013, pp. 18-21.

Cohen, Jean-Louis, "In the Cause of Landscape," in Cohen, Jean-Louis (Ed.), An Atlas of Modern Landscapes, New York: Museum of Modern Art, 2013, pp. 23-47.

García Mercadal, Fernando, “Le Corbusier en Madrid,” in La Gaceta Literaria 34, May 15, 1928.

Lahuerta, Juan José (Ed.), “Espagne”: carnets, Milano: Electa, 2001.

Le Corbusier, Precisions. On the Present State of Architecture and City Planning, Cambridge, MA: MIT Press, 1991 (Translated from Précisions sur un état présent de l'architecture et de l'urbanisme, Paris: Crès, 1930).

Le Corbusier, Towards an Architecture, Los Ángeles: Getty Research Institute, 2008. (Translated from Vers une architecture, Paris: G. Crès, 1923).

Marchant, Hernán, "Villa Ocampo. 1928" (Project 25, DVD 2), in Le Corbusier Plans, Paris: Codex Images International/ Fondation Le Corbusier, Paris, 2005.

Martínez de Guereñu, Laura, "Zeharka begiratzeko markoak: 'Ikustearen baldintza bakarrarekin existitzen naiz bizitza honetan," in Aldiri, Arkitektura eta abar, n 9 (Ttipi), Bilbao, 2012, pp. 14-19.

Ray, Man, Emak Bakia (Basque for Leave me Alone), 1926. (19 min.)

Quetglas, Josep, Les Heures Claires, Sant Cugat del Vallés: Massilia, 2008.

Sebreli, Juan José, Cuadernos, Sudamericana, 2011.

VV. AA., Le Corbusier : Madrid 1928 : una casa - un palacio [exposición], Residencia de Estudiantes, mayo-julio 2010, Residencia de Estudiantes, Madrid, 2010.

VV. AA., Le Pays Basque en 101 sites et monuments, Bordeaux : Le Festin, 2013.

VV. AA., Robert Mallet-Stevens Architecte, Paris: Éditions 15, square de Vergennes, 2005.

VV. AA., Robert Mallet-Stevens: l'oeuvre complète [Ouvrage publié à l'occasion de l'exposition présentée au centre Pompidou, galerie 2, du 27 avril au 29 août 2005], Paris: Centre Pompidou, 2005.

\section{Archives}

Archives Départementales des Pyrénées-Atlantiques, Pôle d’archives de Bayonne et du Pays Basque, Bayonne.

Archives Municipales, Anglet.

Fondation Le Corbusier, Paris.

Fonds Kandinsky, MNAM-CCI, Centre Pompidou, Paris.

Zentrum Paul Klee, Bern. 